\title{
Glimpses of Glory
}

John Bunyan and English Dissent 


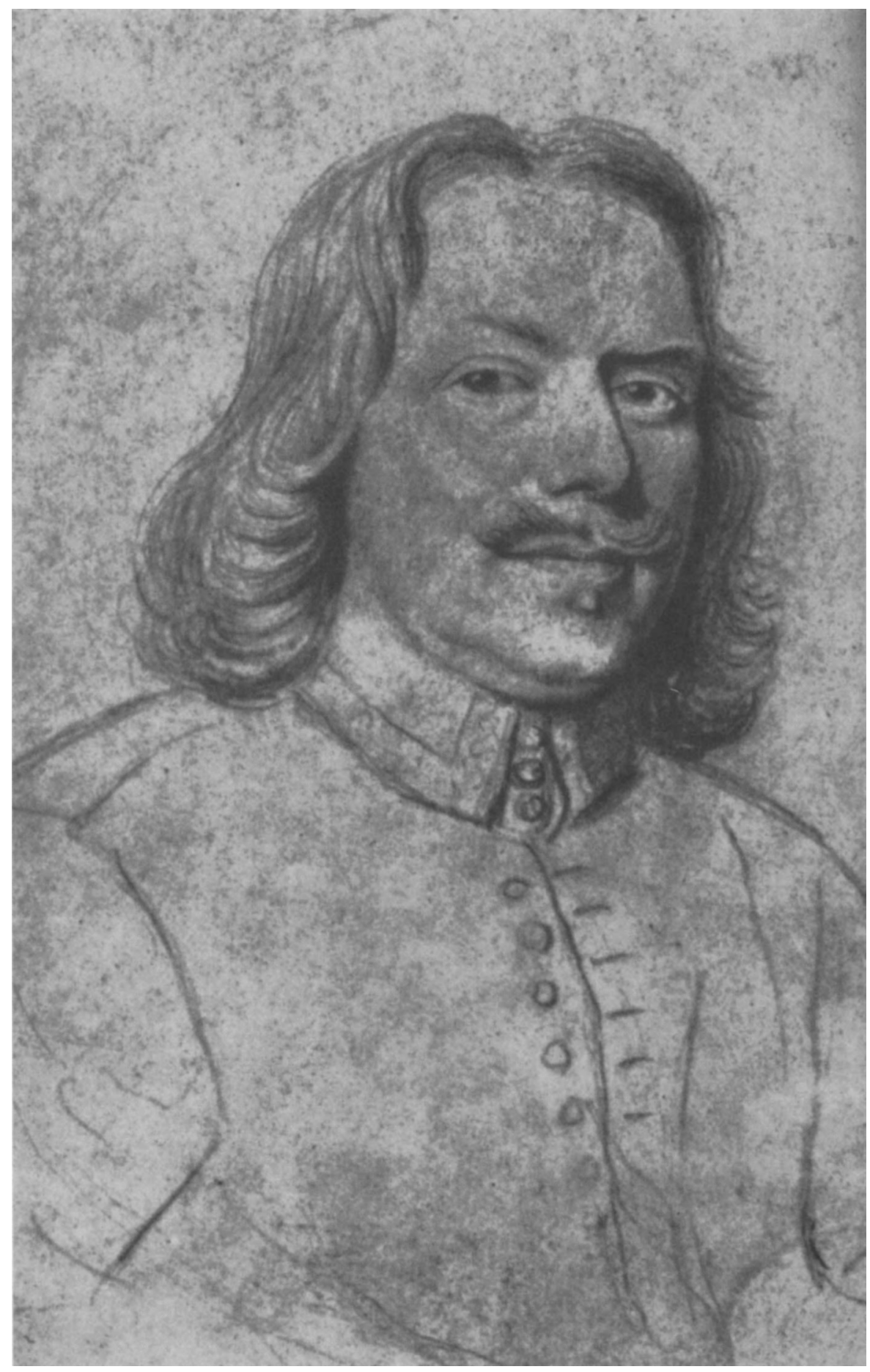




\section{Glimpses of Glory}

JOH N B NYAN

A N D ENGLISH D ISSENT

Richard L. Greaves

Stanford University Press

Stanford, California

2002 


\section{Stanford University Press}

Stanford, California

(C) 2002 by the Board of Trustees of the Leland Stanford Junior University Printed in the United States of America

Library of Congress Cataloging-in-Publication Data

Greaves, Richard L.

Glimpses of glory : John Bunyan and English dissent / Richard L. Greaves.

p. $\mathrm{cm}$.

Includes bibliographical references and index.

ISBN 0-8047-4530-7 (acid-free paper)

1. Bunyan, John, 1628-1688. 2. Christianity and literature-England-

History-17th century. 3. Dissenters, Religious-England-History-17th century. 4. Authors, English-Early modern, 1500-1700-Biography.

5. Christian literature, English-History and criticism. 6. Dissenters, ReligiousEngland-Biography. 7. Bunyan, John, 1628-1688-Religion. 8. Dissenters, Religious, in literature. 9. Christian biography-England I. Title.

PR3332.G66 2002

${ }^{828^{\prime} 407-\mathrm{dc} 21} 2001055039$

This book is printed on acid-free, archival-quality paper.

Original printing 2002

Last figure below indicates year of this printing:

$\begin{array}{llllllllll}11 & 10 & 09 & 08 & 07 & 06 & 05 & 04 & 03 & 02\end{array}$

Typeset at Stanford University Press in 10/13 Minion

Frontispiece: John Bunyan, by Robert White. OCopyright The British Museum 
T O J U D I T H

for sharing and enriching life's pilgrimage 
